\title{
Transgene Expression in Target-Defined Neuron Populations Mediated by Retrograde Infection with Adeno-Associated Viral Vectors
}

\author{
Markus Rothermel, Daniela Brunert, Christine Zabawa, Marta Díaz-Quesada, and Matt Wachowiak \\ Brain Institute and Department of Neurobiology and Anatomy, University of Utah, Salt Lake City, Utah 84112
}

Tools enabling the manipulation of well defined neuronal subpopulations are critical for probing complex neuronal networks. Cre recombinase (Cre) mouse driver lines in combination with the Cre-dependent expression of proteins using viral vectors-in particular, recombinant adeno-associated viral vectors ( $\mathrm{rAAVs}$ ) — have emerged as a widely used platform for achieving transgene expression in specified neural populations. However, the ability of rAAVs to further specify neuronal subsets on the basis of their anatomical connectivity has been reported as limited or inconsistent. Here, we systematically tested a variety of widely used neurotropic rAAVs for their ability to mediate retrograde gene transduction in the mouse brain. We tested pseudotyped rAAVs of several common serotypes (rAAV $2 / 1,2 / 5$, and 2/9) as well as constructs both with and without Cre-dependent expression switches. Many of the rAAVs tested-in particular, though not exclusively, Cre-dependent vectors-showed a robust capacity for retrograde infection and transgene expression. Retrograde expression was successful over distances as large as $6 \mathrm{~mm}$ and in multiple neuron types, including olfactory projection neurons, neocortical pyramidal cells projecting to distinct targets, and corticofugal and modulatory projection neurons. Retrograde infection using transgenes such as ChR2 allowed for optical control or optically assisted electrophysiological identification of neurons defined genetically as well as by their projection target. These results establish a widely accessible tool for achieving combinatorial specificity and stable, long-term transgene expression to isolate precisely defined neuron populations in the intact animal.

\section{Introduction}

The ability to experimentally target defined neuronal subpopulations is critical for understanding brain function. Such tools as targeted gene knock-ins and Cre recombinase (Cre) mouse driver lines in combination with the Cre-dependent expression of proteins allow for the genetic specification and manipulation of neural circuits and systems in the intact brain (Luo et al., 2008; Madisen et al., 2010, 2012; Yizhar et al., 2011). Nonetheless, the ability to target increasingly precise neuronal subsets for robust and stable changes in gene expression is limited by the selectivity of known promoters and by limitations in gene transduction methods. For example, functionally discrete neuronal populations are rarely defined by expression of a single gene and many promoters fail to drive transgene expression sufficiently to alter neuronal function (Luo et al., 2008; McGarry et al., 2010; Zhao et al., 2011).

Received April 17, 2013; revised Aug. 9, 2013; accepted Aug. 12, 2013.

Author contributions: M.R., D.B., and M.W. designed research; M.R., D.B., C.Z., and M.D.-Q. performed research; M.R., D.B., and M.D.-Q. analyzed data; M.R., D.B., and M.W. wrote the paper.

This work was supported by funding from National Institutes of Health (DC06441), the Deutsche Forschungsgemeinschaft (to M.R.), and the USTAR (Utah Science, Technology and Research) Research Initiative at the University of Utah. We thank M. Economo, K.C. Brennan, and T. Bozza for helpful comments on the manuscript; S. Taha and A. Dorval for advice on injection targets; and the University of Pennsylvania and University of North Carolina viral vector cores for providing viral constructs. We thank P. Tvrdik and M. Capecchi for providing Emx1-Cre mice.

The authors declare no competing financial interests.

Correspondence should be addressed to Matt Wachowiak, Brain Institute, University of Utah, Salt Lake City, UT 84103. E-mail:matt.wachowiak@utah.edu.

DOI:10.1523/JNEUROSCI.1618-13.2013

Copyright $\odot 2013$ the authors $\quad 0270-6474 / 13 / 3315195-12 \$ 15.00 / 0$
Viral vectors have the potential to overcome these limitations as they support both genetic and anatomical specification of neuronal subpopulations by incorporating cell type-specific promoters or Cre-dependent expression switches and can drive strong transgene expression (Luo et al., 2008; Betley and Sternson, 2011). Viral vectors that retrogradely transduce neurons via their axon terminals allow for even more precise targeting of neuronal subsets defined by axonal projections or synaptic connectivity (Larsen et al., 2007; Wickersham et al., 2007; Callaway, 2008). Combining retrograde viral infection with Cre-dependent expression enables a combinatorial approach to targeting neuronal subpopulations (for example, isolating a subset of genetically specified cortical pyramidal neurons projecting to a given target), although achieving this has been difficult. To date, most retrograde vectors are based on rabies or herpes virus for retrograde infection, but only a few such vectors mediate Cre-dependent gene expression (Wall et al., 2010; Lo and Anderson, 2011) and their eventual lethality to the host cell limits their use in longterm functional studies or gene-therapy strategies (Wickersham et al., 2007; Osakada et al., 2011). In contrast, recombinant adeno-associated virus (rAAV) vectors are a widely used platform for the delivery of transgenes to CNS neurons due to their ability to mediate long-lasting, relatively stable gene expression and their relative ease of production and handling (Betley and Sternson, 2011). With a few exceptions, however (Kaspar et al., 2002; Passini et al., 2005; Masamizu et al., 2011; Zhang et al., 2013), rAAVs are reported to be weak or ineffective at retrogradely infecting CNS neurons (Chamberlin et al., 1998; Burger et al., 2004; 
Salegio et al., 2013), and retrograde infection by rAAVs using Cre-dependent switches has not been systematically assayed.

Here, we report robust retrograde infection by a variety of widely used rAAV vectors, especially those incorporating Credependent expression switches. Transgene expression via retrograde infection was successful in multiple neuron classes and using multiple rAAV serotypes and enabled the in vivo isolation of genetically defined neuronal subsets with anatomically distinct axonal projections. These results highlight the potential for further development of rAAVs as tools to target specific populations of CNS neurons for experimental or therapeutic applications.

\section{Materials and Methods}

Animals. The following mouse strains of either sex were used, as specified in the text: GAD2-IRES-Cre (Taniguchi et al., 2011), Jax stock \#010802; PCdh21-Cre (Nagai et al., 2005), Gene Expression Nervous System Atlas (GENSAT) Project, Mutant Mouse Regional Resource Centers (MMRRC) stock \#030952-UCD; Slc6a4 [serotin reuptake transporter (SERT)]-Cre, GENSAT Project, MMRRC stock \#031028-UCD, CCKIRES-Cre (Taniguchi et al., 2011), Jax Stock \#012706; Ai9 (Madisen et al., 2010), Jax stock \#007905; TH-Cre, Jax stock \#008601; Emx1-IRES-Cre (Gorski et al., 2002) Jax stock \#005628. All procedures were performed following National Institutes of Health Guide for the Care and Use of Laboratory Animals and were approved by the University of Utah Institutional Animal Care and Use Committee.

Viral vectors. Viral vectors used were obtained from the viral vector cores of the University of Pennsylvania or the University of North Carolina, as specified. All vectors were from stock batches available for general distribution. Injection of Cre-dependent vectors was performed in mice that were homozygous for the allele driving Cre expression; injections in heterozygous animals were also successful but are not described here. Virus injection was performed by stereotaxic targeting of specified brain areas using previously described procedures (Wachowiak et al., 2013). The specified volumes of virus were delivered through a 33 or 30 gauge metal needle at a rate of $0.1 \mu \mathrm{l} / \mathrm{min}$. Mice were between 4 and 12 weeks of age at the time of virus injection and individually housed after injection for 14-28 d before evaluating for transgene expression. The viral vectors used, with their abbreviated names as used in the text, were as follows: AAV2/1.hSynap.FLEX.GCaMP3.3.WPRE.SV40 (2/1.FLEX.GCaMP3); AAV2/1.CAGGS.FLEX.ChR2-tdTomato.SV40 (2/1.FLEX.ChR2tdTomato); AAV2/1.hSynap.FLEX.GCaMP5G(GCaMP3-T302L.R303P. D380Y).WPRE.SV40 (2/1.FLEX.GCaMP5G); AAV2/1.hSynap.EGFP. WPRE.bGH (2/1.EGFP); AAV2/1.CB7.CI.mCherry.WPRE.rBG (2/1. $m$ Cherry); AAV2/5.EF1a.DIO.hChR2(H134R)-EYFP.WPRE.hGH (2/5. DIO.hChR2-EYFP); AAV2/9.EF1a.DIO.hChR2(H134R)-EYFP.WPRE. HGHpA(2/9.DIO.hChR2-EYFP);AAV2/1.hSynap.FLEX.GCaMP6f.WPRE. SV40 (2/1.FLEX.GCaMP6f);AAV2/1.hSynap.GCaMP5G(GCaMP3-T302L. R303P.D380Y).WPRE.SV40 (2/1.GCaMP5G); AAV2/5.EF1a.DIO. mCherry (2/5.DIO.mCherry); AAV2/5.EF1a.DIO.hChR2(H134R)mCherry(2/5.DIO.hChR2-mCherry);AAV2/1.hSyn.FLEX.iGluSnFr.WPRE. SV40 (2/1.FLEX.iGluSnFr); AAV2/1.CAG.FLEX.tdTomato.WPRE.bGH (2/ 1.FLEX.tdTomato).

Histology. Mice were deeply anesthetized and perfused with $4 \%$ paraformaldehyde. To evaluate transgene expression, brains were processed and vibratome-sectioned as described previously (Wachowiak et al., 2013) and expression evaluated from native fluorescence without immunohistochemical amplification. To assay for coexpression with the mitral/tufted cell (MTC)-specific marker Tbx21, brains were cryosectioned and processed for immunohistochemistry as described in Wachowiak et al. (2013). Briefly, cryoprotected brains were embedded in optimum cutting temperature compound (Tissue-Tek, Sakura-Fintek) and cut coronally $(15-30 \mu \mathrm{m})$ with a cryostat. Sections were incubated with primary antibody (rabbit antiTbx21,1:1000; kindly provided by Y. Yoshihara, RIKEN) overnight at $4^{\circ} \mathrm{C}$, followed by incubation with Alexa543-conjugated goat anti-rabbit secondary antibody (1:1000; A-11010, Invitrogen) at room temperature (RT) for $1 \mathrm{~h}$. Viral-driven GCaMP expression was enhanced by staining with FITCconjugated GFP antibody (1:150; \#ab6662, Abcam) for $4 \mathrm{~h}$ at RT to counter deteriorated native fluorescence due to cryotreatment. For display and for cell counts, image stacks were obtained with an Olympus FV10i confocal laser scanning microscope.

Recordings and optical stimulation. For in vivo recordings, mice were anesthetized with pentobarbital $(50 \mathrm{mg} / \mathrm{kg})$ and secured in a stereotaxic device (Kopf Instrument) or custom head bar. Body temperature was maintained at $37^{\circ} \mathrm{C}$. A small $(\sim 1 \times 1 \mathrm{~mm})$ craniotomy was performed over one olfactory bulb $(\mathrm{OB})$ and the dura removed. Extracellular recordings were obtained from units in the dorsal $\mathrm{OB}$ using a 16-channel electrode (A1x16-5mm50-413-A16, NeuroNexus) and an RZ5 digital acquisition system [Tucker Davis Technologies (TDT)]. Electrode depth was monitored with a digital micromanipulator (MP-225, Sutter Instruments). Custom scripts in TDT were used to control data acquisition and optical stimulation. Criteria for selecting units for analysis were as described in Carey and Wachowiak (2011). In vivo whole-cell recordings were performed using 4-6 M $\Omega$ glass electrodes drawn on a horizontal puller (P97, Sutter Instruments) and filled with an intracellular solution consisting of the following (in $\mathrm{mm}$ ): $135 \mathrm{~K}$-gluconate, $4 \mathrm{KCl}, 10 \mathrm{HEPES}$, 10 phosphocreatine, 4 MgATP, $0.3 \mathrm{GTP}$, and buffered to $\mathrm{pH} 7.3$ with $\mathrm{KOH}$ (Sigma-Aldrich). In some experiments, internal solution contained $20 \mu \mathrm{m}$ sulforhodamine 101 (Invitrogen) and the following (in $\mathrm{mm}$ ): $120 \mathrm{~K}$-gluconate, $20 \mathrm{KCl}, 10 \mathrm{HEPES}, 7$ diTrisPhCr, 4 Na2ATP, 2 $\mathrm{MgCl}$ 2, 0.3 Tris-GTP, 0.2 EGTA, and buffered to $\mathrm{pH} 7.3$ with $\mathrm{KOH}$ (Sigma-Aldrich). For in vitro recordings, OB slices (300 $\mu \mathrm{m}$ thickness) were prepared from adult mice using previously published protocols (Wachowiak et al., 2013). Slices were maintained at $33^{\circ} \mathrm{C}$ and recordings made using the same pipette resistance and internal solution as for the in vivo recordings. All whole-cell recordings were performed in currentclamp mode using a Multiclamp 700A amplifier (Molecular Devices) and data acquisition and optical stimulation were controlled with pClamp10 (Molecular Devices). For optical stimulation, light was presented using a $470 \mathrm{~nm}$ LED and controller (LEDD1B, Thorlabs) and a $1 \mathrm{~mm}$ optical fiber or a $473 \mathrm{~nm}$ diode-pumped solid-state laser (LaserWave) and 200 $\mu \mathrm{m}$ fiber, each positioned within $1 \mathrm{~mm}$ of the surface of the dorsal $\mathrm{OB}$ or the OB slice. Total light power emitted was typically $7-12 \mathrm{~mW}$ for the 1 $\mathrm{mm}$ fiber and $\sim 1 \mathrm{~mW}$ for the $200 \mu \mathrm{m}$ fiber.

\section{Results}

\section{Retrograde infection of $\mathrm{OB}$ projection neurons by rAAVs}

We first tested the ability of rAAVs to drive transgene expression via retrograde axonal infection in the mouse olfactory pathway. The olfactory bulb $(\mathrm{OB})$ was used as a test bed for characterizing retrograde infection because its principal neurons, mitral/tufted cells (MTCs), constitute an anatomically and functionally heterogeneous group with subpopulations projecting to multiple forebrain targets and having distinct dendritic and laminar organization (Macrides and Schneider, 1982; Nagayama et al., 2010; Igarashi et al., 2012). To selectively target MTCs, we used a transgenic mouse line (PCdh21-Cre) that, within the forebrain, expresses Cre primarily in MTCs (Nagai et al., 2005; Mitsui et al., 2011; Wachowiak et al., 2013). Injection of rAAV containing Cre-dependent expression constructs (e.g., 2/1.FLEX.GCaMP3; 2/1.FLEX.ChR2-tdTomato) into the OB leads to expression that appears restricted to MTCs, with the majority of somata in the mitral cell layer and deep glomerular layer (Fig. 1A) and fewer somata in the external plexiform layer. This expression pattern matches that described for mRNA expression of PCdh21 in the OB (Nakajima et al., 2001), indicating that the rAAV2/1 serotype has sufficient tropism to enable efficient transduction of the Cre-dependent transgene in OB MTCs. The PCdh21+ MTC population likely includes superficial and external tufted cells with somata in the glomerular layer, whose axonal projections either remain intrinsic to the $\mathrm{OB}$ or project only to the most anterior portions of olfactory cortex (Schoenfeld et al., 1985; Shipley et al., 2004; Ghosh et al., 2011; Igarashi et al., 2012).

To test for retrograde infection of OB MTCs with Credependent rAAV2/1 constructs, we injected virus into anterior 
A OB injected (PCdh21-Cre)
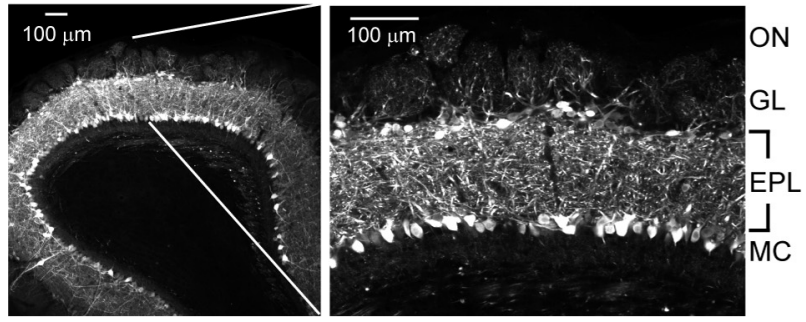

$\mathrm{B}$ aPC injected
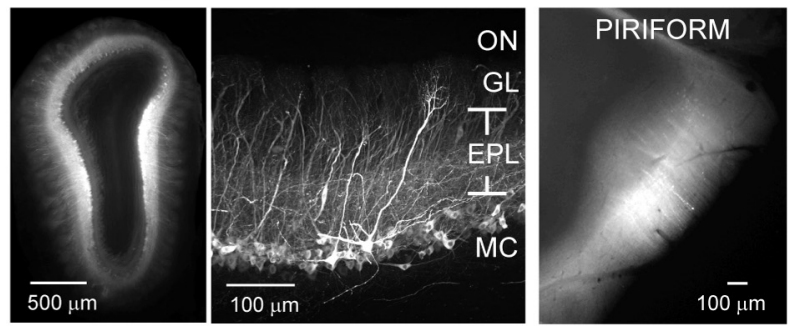

\section{C pPC injected}

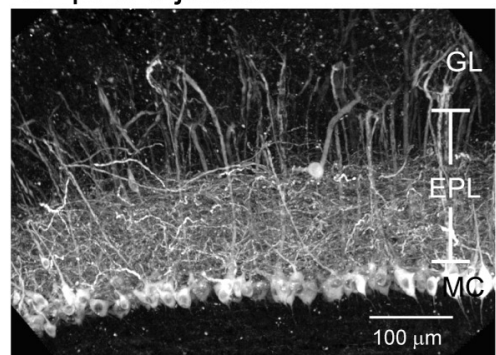

D PLCo injected

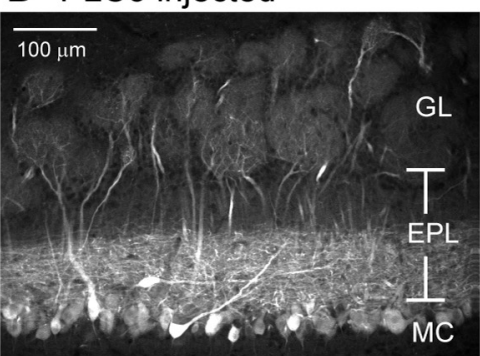

E MeA injected

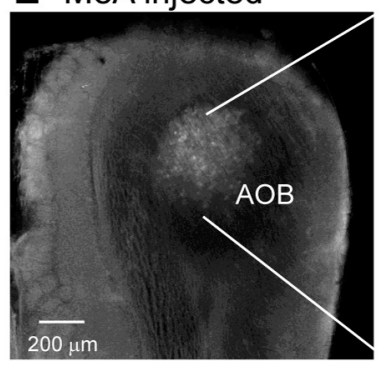

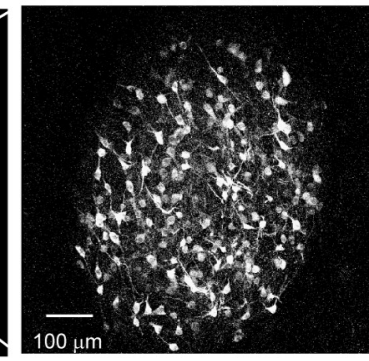

Figure 1. Cre-dependent and target-specific transgene expression in OB output neurons via retrograde rAAV infection. $A$, Expression of GCaMP 3 in MTCs after injection of Cre-dependent virus (2/1.FLEX.GCaMP3) into the OB of a PCdh21-Cre mouse. Right image shows higher-magnification view of the dorsal OB. Expression is strongest in the dorsal half of the OB and apparent in somata in the mitral cell layer (MC) and the superficial external plexiform layer (EPL)/deep glomerular layer (GL). Dendritic processes are also apparent throughout the EPL. B, GCaMP3 expression after injection of 2/1.FLEX.GCaMP3 into aPC of a PCdh21-Cre mouse. Left, Low-magnification, epifluorescence image showing heavy expression in MTCs throughout the OB. Middle, Confocal stack showing dense expression in cells predominately in the MC layer (compare with $\boldsymbol{A}$ ). Right, Axon terminals of GCaMP3-expressing neurons in piriform cortex. Note the lack of cell bodies expressing GCaMP3 in piriform. $\boldsymbol{C}, \boldsymbol{D}, \mathrm{GCaMP3}$ expression after injection of 2/1.FLEX.GCaMP3 into (C) posterior piriform cortex (PPC) and (D) posterolateral cortical amygdala (PLCo). Injection in both areas leads to preferential expression in mitral and deep tufted cells, with dendritic branching restricted to the deep half of the EPL. E, Expression of GCaMP3 after 2/1.FLEX.GCaMP3 injection into medial amygdala (MeA). Expression is strongest in mitral cells of the accessory $0 B(A O B)$.

piriform cortex (aPC), a major target of MTC axons, in PCdh21Cre mice. We injected a relatively large volume $(400-1000 \mathrm{~nL})$ of virus to cover a large extent of aPC. Injection of AAV2/1.FLEX. GCaMP3 into aPC led to widespread expression of GCaMP3 in MTCs throughout the OB (Fig. $1 B$, left; $n=25$ animals). Somata at the injection site in $\mathrm{ACC}$, as well as centrifugal neurons projecting from aPC to the OB (Haberly and Price, 1978; Shipley and Adamek, 1984; Boyd et al., 2012) do not express the transgene as they do not contain Cre (Fig. $1 B$, right). Transgene expression after retrograde rAAV infection occurred in MTCs throughout the entire extent of the $\mathrm{OB}$, in contrast to localized expression seen with direct $\mathrm{OB}$ injection (Fig. 1A, left). Retrograde infection also led to preferential expression in neurons in the mitral cell layer compared with direct $\mathrm{OB}$ infection. In retrogradely infected mice, $85 \%$ of labeled somata ( 412 cells, 10 mice) were located in the mitral cell layer, with the remainder in the external plexiform layer. In mice injected directly into the OB, only $61 \%$ of counted somata ( 885 cells, six mice) were located in the mitral cell layer, with the remaining in the external plexiform layer or glomerular layer (Fig. 1A). This difference likely reflects the exclusion of PCdh21 + cell types that do not project to aPC. Retrograde infection was robust, typically leading to expression in a high fraction of all PCdh21+ mitral cells: in PCdh21-Cre mice expressing GCaMP after retrograde infection into aPC, $81 \%$ of neurons in the mitral cell layer that expressed the MTC-specific marker Tbx21 (Nagai et al., 2005; Mitsui et al., 2011) were also positive for GCaMP (351 of 433 cells, three mice). Retrograde infection was also reproducible: in $>50$ injections into aPC in PCdh21-Cre mice, we have achieved widespread expression in MTCs in $\sim 80 \%$ of cases, with most failures attributable to errors in stereotaxic targeting. Retrograde infection was also effective using injection volumes as small as $100 \mathrm{~nL}$ (two mice, four injections), though fewer MTCs were labeled.
To establish the usefulness of retrograde infection for isolating subsets of genetically defined neurons based on their axonal projections, we injected virus into different olfactory cortical areas known to be targeted by distinct populations of OB MTCs. These experiments also helped to confirm that transgene expression was in fact due to retrograde infection rather than bulk spread of injected virus from forebrain areas to the OB. One subpopulation of MTCs includes neurons with somata in the mitral cell layer and lateral dendrites that remain restricted to the deep half of the external plexiform layer and which project to posterior piriform cortex and cortical amygdala (Haberly and Price, 1977; Scott et al., 1980; Schneider and Scott, 1983). Another subpopulation of PCdh21 + MTCs includes mitral cells of the accessory OB, which project to medial amygdala but not to piriform cortex (Scalia and Winans, 1975). Consistent with these anatomically defined divisions, we found that Cre-dependent $\mathrm{rAAV}$ injection (2/1.FLEX.GCaMP3) into posterior piriform (seven mice, 12 injections) or cortical amygdala (two mice, four injections) led to expression almost exclusively in mitral cells, with 85 and $90 \%$ of GCaMP3-expressing neurons ( $n=124$ and 142 cells) having somata in the mitral cell layer for posterior piriform and cortical amygdala injections, respectively. Furthermore the lateral dendrites of GCaMP3-expressing neurons were restricted to the deep external plexiform layer of the main OB (Fig. 1C,D). Injection into medial amygdala, in contrast, led to expression solely in mitral cells of the accessory $\mathrm{OB}$ (Fig. 1E; two mice, four injections). These results argue that the observed expression is not due to bulk spread of virus from the injection site, and that retrograde viral infection can be used to isolate neuronal subpopulations defined on the basis of their axonal projection patterns. We also note that the distance from cortical or medial amygdala to the $\mathrm{OB}$ is $\sim 5.3-6.1 \mathrm{~mm}$, indicating that retrograde infection is effective over a considerable distance. 
Table 1. rAAV constructs tested for retrograde infection in OB projection neurons ${ }^{a}$

\begin{tabular}{|c|c|c|c|c|c|}
\hline Construct & rAAV serotype & Source & Titer & $n$ (mice) & Retrograde infection \\
\hline \multicolumn{6}{|l|}{ Cre-dependent } \\
\hline FLEX.GCaMP3 & $2 / 1$ & University of Pennsylvania & $5.6 \times 10^{12}-2.1 \times 10^{13}$ & 25 & Yes \\
\hline FLEX.GCaMP5G & $2 / 1$ & University of Pennsylvania & $1.1 \times 10^{13}-1.5 \times 10^{13}$ & 30 & Yes \\
\hline FLEX.GCaMP6f & $2 / 1$ & University of Pennsylvania & $1.7 \times 10^{12}-2.9 \times 10^{13}$ & 14 & Yes \\
\hline FLEX.ChR2-tdTomato & $2 / 1$ & University of Pennsylvania & $5.3 \times 10^{11}-1.4 \times 10^{12}$ & 2 & Yes \\
\hline FLEX.GGluSnFr & $2 / 1$ & University of Pennsylvania & $1.1 \times 10^{13}$ & 1 & Yes \\
\hline DI0.hChR2-EYFP & $2 / 5$ & University of Pennsylvania & $6.7 \times 10^{11}-2.0 \times 10^{13}$ & 4 & Yes \\
\hline DI0.hChR2-mCherry & $2 / 5$ & University of North Carolina & $6.0 \times 10^{12}$ & 2 & Yes \\
\hline DI0.mCherry & $2 / 5$ & University of North Carolina & $4.0 \times 10^{12}$ & 2 & Yes \\
\hline \multicolumn{6}{|l|}{ Cre-independent } \\
\hline GCaMP5G & $2 / 1$ & University of Pennsylvania & $2.3 \times 10^{12}$ & 11 & No \\
\hline mCherry & $2 / 1$ & University of Pennsylvania & $5.3 \times 10^{12}$ & 2 & Yes \\
\hline eGFP & $2 / 1$ & University of Pennsylvania & $2.5 \times 10^{13}$ & 2 & No \\
\hline
\end{tabular}

${ }^{a}$ Table summarizes rAAV constructs that were injected into anterior piriform cortex and evaluated for expression in OB projection neurons. Reported $n$ is for number of mice but we typically performed two injections per animal. Vectors are classified as mediating successful retrograde expression if we observed expression in $>1000$ B neurons in all injections in which successful stereotaxic targeting was confirmed. Typically, however, unsuccessful vectors displayed $<8$ labeled neurons per injection. Additional constructs and serotypes tested in different brain regions are described in the text and Table 2.

A aPC injected (PCdh21-Cre). 2/1.GCaMP5G

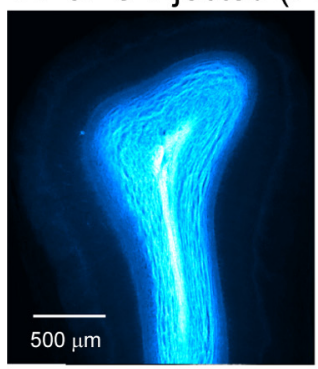

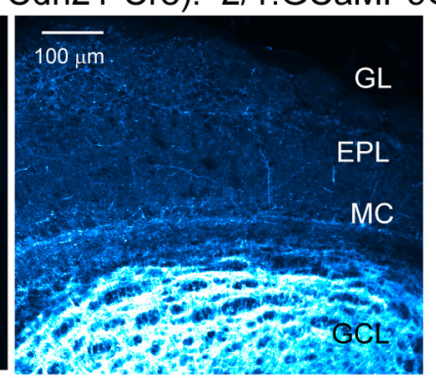

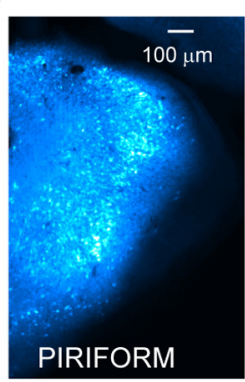

\section{B aPC injected.}

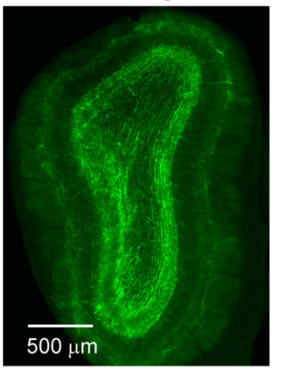

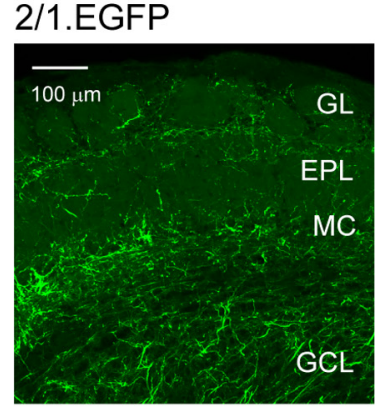

\section{2/1.FLEX.GCaMP5G}

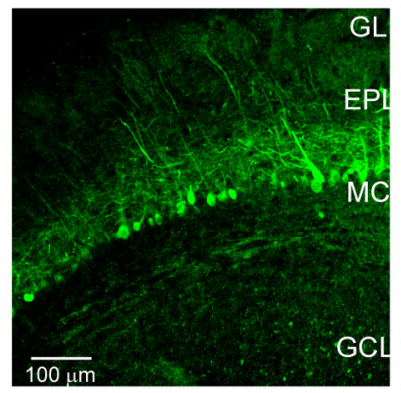

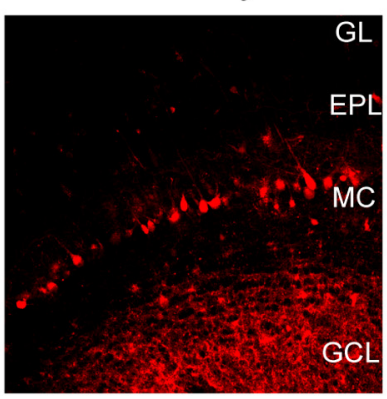

overlay

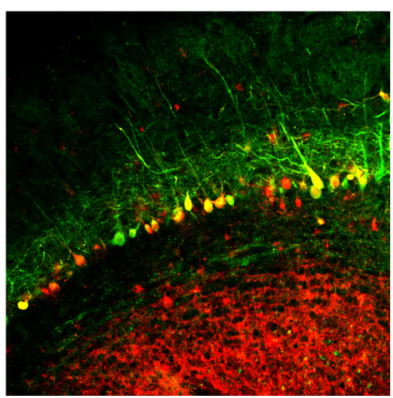

Figure 2. Differential ability of constitutive rAAV vectors to drive retrograde expression in OB projection neurons. $A, G C a M P 5 G$ expression in centrifugal axons in the $0 B$ after injection of the constitutive rAAV 2/1.GCaMP5G into aPC of a PCdh21-Cre mouse. Left, Middle, Low-magnification and high-magnification images showing strong labeling of axonal processes in the granule cell layer (GCL) throughout the OB but not cell bodies expressing GCaMP5G. Right, Image of aPC, near injection site, showing numerous GCaMP5G-expressing cell bodies. B, Similar labeling of centrifugal axons in the $\mathrm{OB}$ after injection of $\mathrm{rAAV} 2 / 1$.EGFP into aPC. Here, axon terminals are apparent in the $\mathrm{GCL}$ as well as around the periphery of glomeruli in the glomerular layer (GL), but no cell bodies are apparent in the OB. C, Robust retrograde expression mediated by the constitutive rAAV 2/1.mCherry. 2/1.mCherry was coinjected with 2/1.FLEX.GCaMP5G into aPC of a PCdh21-Cre mouse. Left image shows GCaMP5G expression in the OB (green). Middle image shows mCherry expression (red). Right image shows overlay. GCaMP5G expression is apparent primarily in mitral cells, while $\mathrm{mCherry} \mathrm{expression} \mathrm{is} \mathrm{apparent} \mathrm{in} \mathrm{mitral} \mathrm{cells} \mathrm{and} \mathrm{in} \mathrm{axons} \mathrm{in} \mathrm{the} \mathrm{granule} \mathrm{cell} \mathrm{layer,} \mathrm{consistent} \mathrm{with} \mathrm{both} \mathrm{retrograde} \mathrm{infection} \mathrm{of} \mathrm{mitral} \mathrm{cells} \mathrm{and} \mathrm{direct} \mathrm{infection} \mathrm{of} \mathrm{neurons} \mathrm{projecting} \mathrm{from}$ aPC to the $\mathrm{OB}$.

\section{Robust retrograde infection by rAAVs}

Because retrograde infection by rAAVs has been reported as weak or ineffective in some cases and effective in others (Chamberlin et al., 1998; Burger et al., 2004; Wachowiak et al., 2013; Zhang et al., 2013), we evaluated the robustness of this phenomenon by testing for expression of different Cre-dependent transgene constructs and serotypes. We observed similar success of retrograde infection for identical Cre-dependent constructs encoding multiple transgenes and using multiple promoters (Table 1), and across multiple production lots obtained from the same source over 24 months. Both $2 / 1$ and 2/5 serotypes resulted in similarly strong retrograde expression levels (Table 1).
We next tested the ability of constitutive (Cre-independent) constructs to drive transgene expression after retrograde infection using the same injection protocol in PCdh21-Cre mice. Injection of the constitutive GCaMP5G construct (2/1.GCaMP5G) led to expression in neurons throughout aPC and in the terminals of corticofugal axons in the granule cell and glomerular layers of the $\mathrm{OB}$ (Fig. $2 A$ ), indicating effective viral transduction around the injection site followed by anterograde labeling of axonal projections from piriform. However, this virus failed to drive expression in MTCs of the OB (11 mice, 22 injections; eight cells total could be identified in the MCL in 14 sections in five of the mice). Likewise, injection of 2/1.EGFP, the construct used in a large- 

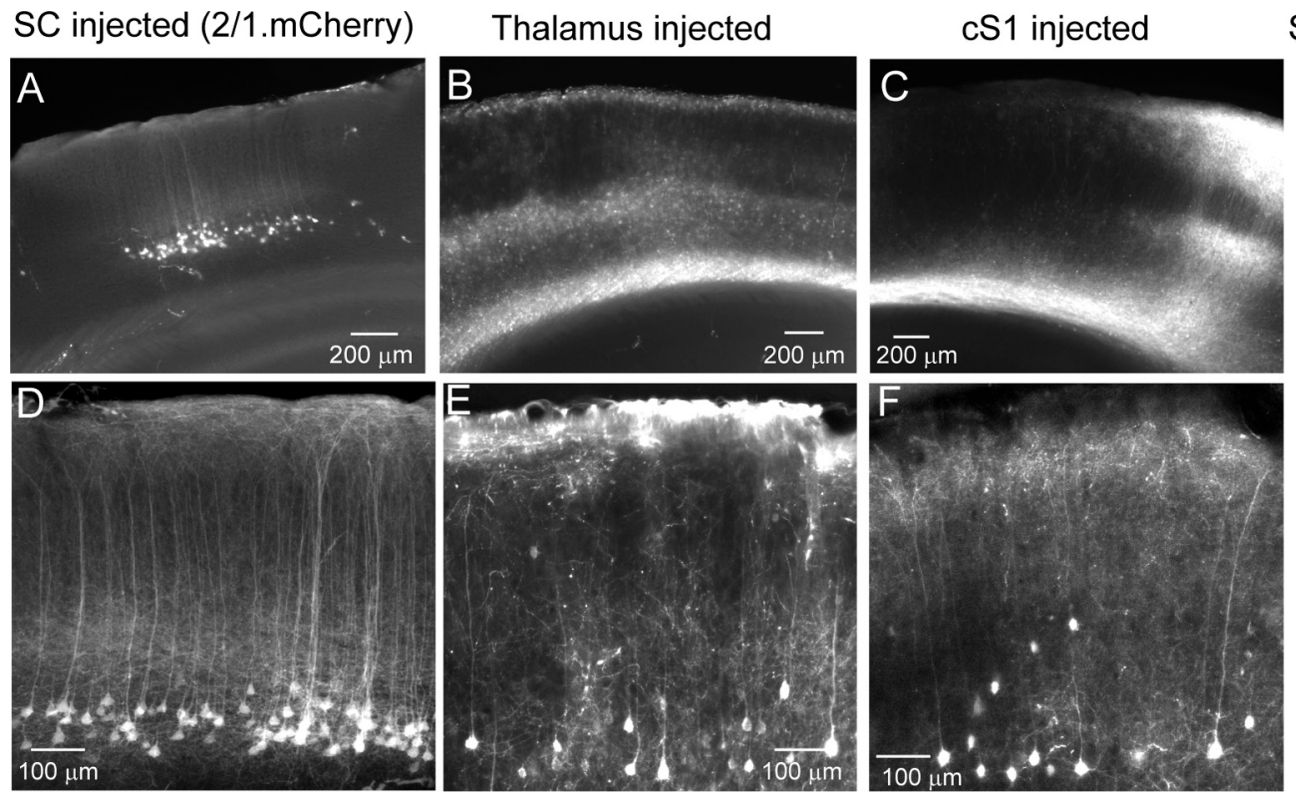
SC, cS1 injected (Emx1-Cre)

Figure 3. Retrograde transgene expression in cortical pyramidal neurons projecting to different targets. $\boldsymbol{A}-\boldsymbol{F}$, Low-magnification epifluorescence images (top) and highermagnification confocal stacks (bottom) of mCherry fluorescence in $\mathrm{S} 1$ after injection of rAAV2/1.mCherry into superior colliculus $(\boldsymbol{A}, \boldsymbol{D}, \mathrm{SC})$, thalamus $(\boldsymbol{B}, \boldsymbol{E})$, and contralateral $S 1(\boldsymbol{C}, \boldsymbol{F}$, CS1). For all images, the pial surface is toward the top. $\mathrm{mCherry-expressing} \mathrm{layer} 5$ pyramidal neurons are apparent in each preparation. In the contralateral-injected animal $(\boldsymbol{C}, \boldsymbol{F})$, the brightest fluorescence is from anterograde labeling of contralateral-projecting neurons infected at the injection site, but mCherry-expressing cell bodies are apparent in layer 5 (F). $\boldsymbol{G}$, Injection of two different Cre-dependent viruses into $\mathrm{SC}$ and $\mathrm{S} 1$ in the same EmX1-Cre mouse labels distinct populations of pyramidal neurons. 2/1.FLEX.tdTomato (red) was injected into CS1; 2/1.FLEX.GCaMP3 into SC. Low-magnification image (top) shows GCaMP3-expressing somata and anterograde mCherry labeling in contralaterally projecting axon terminals. Retrogradely expressing somata from $\mathrm{C} 1$ are less clear at this magnification and in this section, but are apparent in higher-magnification confocal stacks (bottom). Retrogradely labeled pyramidal neuron populations from SC and $\mathrm{C} 1$ are nonoverlapping.

scale effort to map anterograde projection patterns across the mouse brain (Allen Brain Institute, http:/help.brain-map.org/ display/mouseconnectivity/Documentation), also showed robust expression in aPC neurons and their corticofugal projections to the OB but no expression in MTCs (two mice, four injections; no cells could be identified in the MCL in eight sections; Fig. 2B). These data are consistent with previous results showing an absence of retrograde labeling when using rAAVs with constitutive constructs (Chamberlin et al., 1998; Skorupa et al., 1999; Heuer et al., 2002; Passini et al., 2002). These results also suggest that retrograde infection is not facilitated by the presence of Cre recombinase in infected neurons.

Surprisingly, however, a third Cre-independent construct, 2/1.mCherry, was highly effective at driving transgene expression via retrograde infection. To characterize this, we coinjected 2/1.mCherry virus into aPC of PCdh21-Cre mice along with the Cre-dependent 2/1.FLEX.GCaMP3 vector described above (two mice, four injections). In these experiments, coexpression of mCherry and GCaMP3 was prevalent in OB MTCs (Fig. 2C), with clear coexpression in 92\% (292 of 317 GCaMP-expressing cells) of visible cells in the mitral cell layer. While mCherry was visible in the axon terminals of corticofugal projections from aPC to the $\mathrm{OB}$, we observed no mCherry expression in neurons of the granule cell layer, as might be expected if the virus spread by bulk movement to the OB. These experiments demonstrate that at least some Cre-independent rAAV vectors are capable of driving robust transgene expression through retrograde infection via axonal projections, consistent with a recent report for $2 / 1$.hChR2 (Zhang et al., 2013). Notably, these results also demonstrate that simultaneous infection by two different rAAVs and retrograde expression of distinct transgenes is possible in the same neuron.

\section{Retrograde transgene expression in target-defined cortical pyramidal neuron subsets}

We next assessed the ability of rAAVs to retrogradely infect other projection neuron types. Layer 5 pyramidal neurons are a major source of output from neocortex and project to diverse targets. There is evidence that layer 5 subpopulations projecting to different targets have distinct functional and morphological properties (Hattox and Nelson, 2007; Larsen et al., 2007). To assess the ability of retrograde $\mathrm{AAAV}$ infection to define target-specific cortical neuron populations, we investigated projections from mouse primary somatosensory cortex (S1), in which different subpopulations of layer 5 pyramidal neurons have been previously identified using retrograde tracing with a recombinant rabies virus (Larsen et al., 2007). We used the constitutive rAAV 2/1.mCherry construct, injected into three different targets of S1 layer 5 pyramidal neurons: superior colliculus, thalamus, and contralateral S1.

2/1.mCherry injection into these three targets (six mice; one injection in each) led to mCherry expression patterns that largely recapitulated those achieved with recombinant rabies virus (Larsen et al., 2007). Injection into superior colliculus led to strong expression in layer 5 pyramidal neurons within a spatially restricted region of $\mathrm{S} 1$ (Fig. $3 A, D$ ). Injection into thalamus also drove strong mCherry expression in layer 5 pyramidal neurons, although across a broader area of S1 (Fig. $3 B, E$ ). Injection into S1 led to mCherry expression in layer 5 pyramidal neurons in contralateral S1 (Fig. 3C,F). S1 injection also drove strong expression in layer 5 neurons around the injection site, whose axons could be seen coursing through the corpus callosum and terminating throughout contralateral S1 (Fig. 3C,F). This last experiment demonstrates the ability of rAAVs to infect neurons directly 


\section{A OB injected (CCK-Cre)}

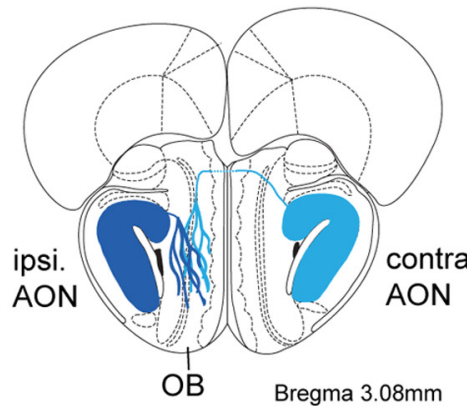

Bregma $3.08 \mathrm{~mm}$

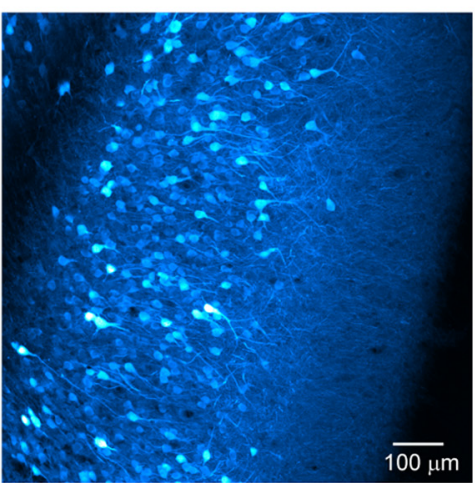

ipsi. AON
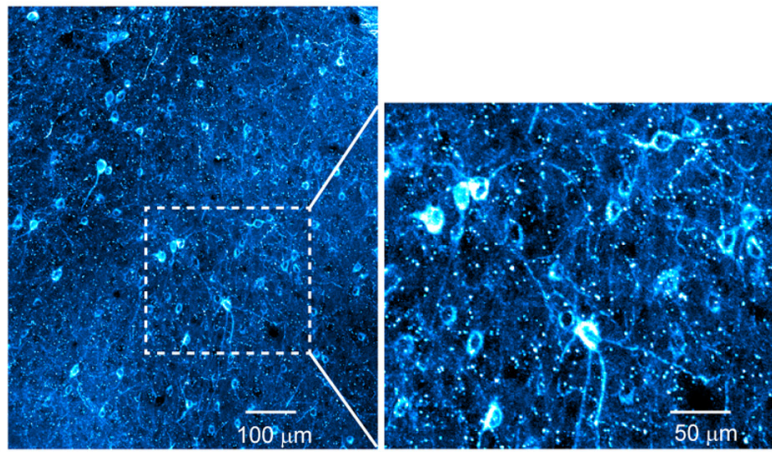

contra. AON
B
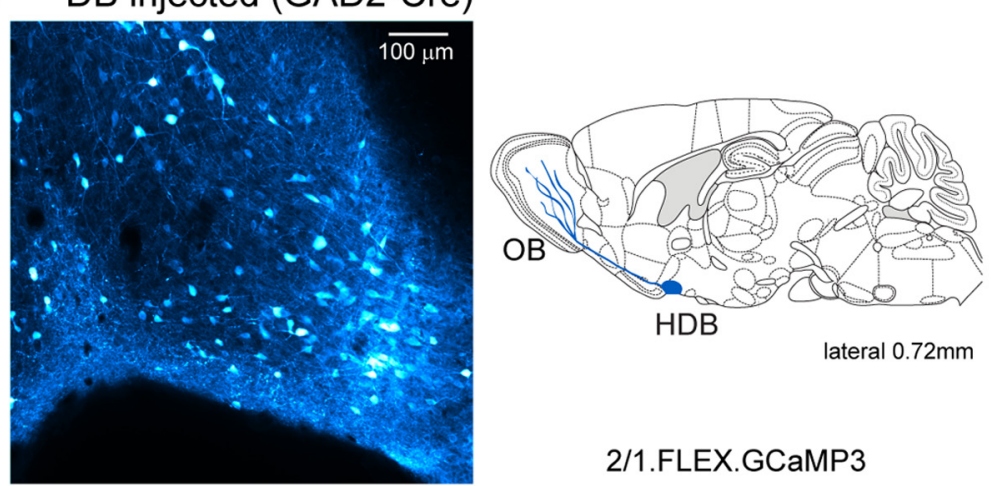

lateral $0.72 \mathrm{~mm}$

2/1.FLEX.GCaMP3

\section{BLA injected (SERT-Cre)}

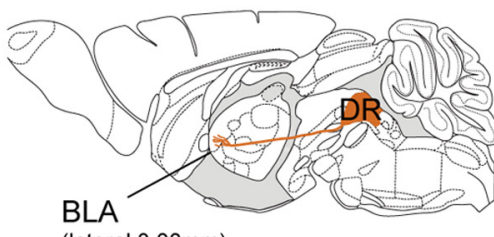

lateral $-0.04 \mathrm{~mm}$
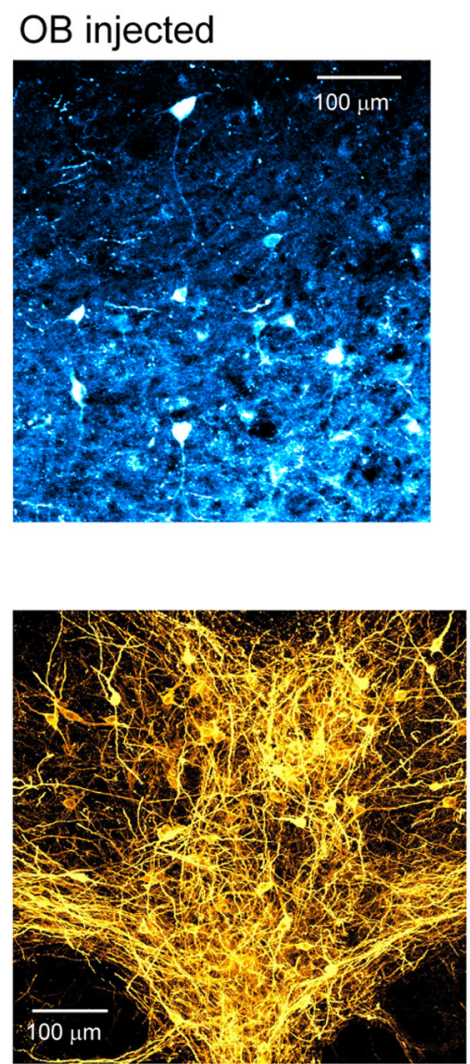

2/9.DIO.hChR2-EYFP

Figure 4. Retrograde transgene expression in diverse populations of centrifugal projection neurons. $A$, Retrograde expression of GCaMP3 in CCK-positive neurons projecting from AON to the OB. Left image shows confocal stack of GCaMP3 fluorescence in the ipsilateral AON after injection of 2/1.FLEX.GCaMP3 into the OB of a CCK-Cre mouse, with dense expression in neurons throughout AON. Right images show confocal stack of GCaMP3 fluorescence in the contralateral AON of the same mouse, showing weaker but still clear expression in numerous AON neurons. Right, Zoom of outlined region showing details of GCaMP3-expressing neurons. $\boldsymbol{B}$, Retrograde expression of GCaMP3 in GABAergic neurons projecting from the basal forebrain to the $0 B$. Left, Image of GCaMP3 fluorescence in the nucleus of the diagonal band of Broca (DB) after injecting 2/1.FLEX.GCaMP3 into DB of a GAD2-Cre mouse. Right, Image of GCaMP fluorescence in the HDB after injection of rAAV2/ 1.Flex.GCaMP3 into the OB of a GAD2-Cre mouse, showing appreciable numbers of GCaMP3-expressing neurons and their processes. Section from atlas (Paxinos and Franklin, 2001) illustrates targeted injection sites and source of labeled projections. C, Retrograde expression of ChR2-EYFP in serotonergic neurons projecting to basolateral amygdala. Image shows EYFP fluorescence in the dorsal raphe after injection of 2/9.DI0.hChR2(H134R)-EYFP into the basolateral amygdala (BLA) of a SERT-Cre mouse. Numerous ChR2-EYFP-expressing somata are apparent clustered along the midline.

through their somata, in contrast to recombinant rabies variants, which selectively infect neurons via their axon terminals (Kelly and Strick, 2000). The number of retrogradely infected pyramidal neurons apparent after superior colliculus or thalamus injection appeared similar to or greater than those reported using recombinant rabies virus (Larsen et al., 2007), indicating a robust ability of this construct to drive transgene expression after axonal infection. Finally, we demonstrated that the retrograde infection capabilities of these rAAVs enables the differential labeling of pyramidal neuron subpopulations projecting to distinct targets in the same animal. We used Emx1-Cre mice, which express Cre in glutamatergic neurons of neocortex (Gorski et al., 2002) and 

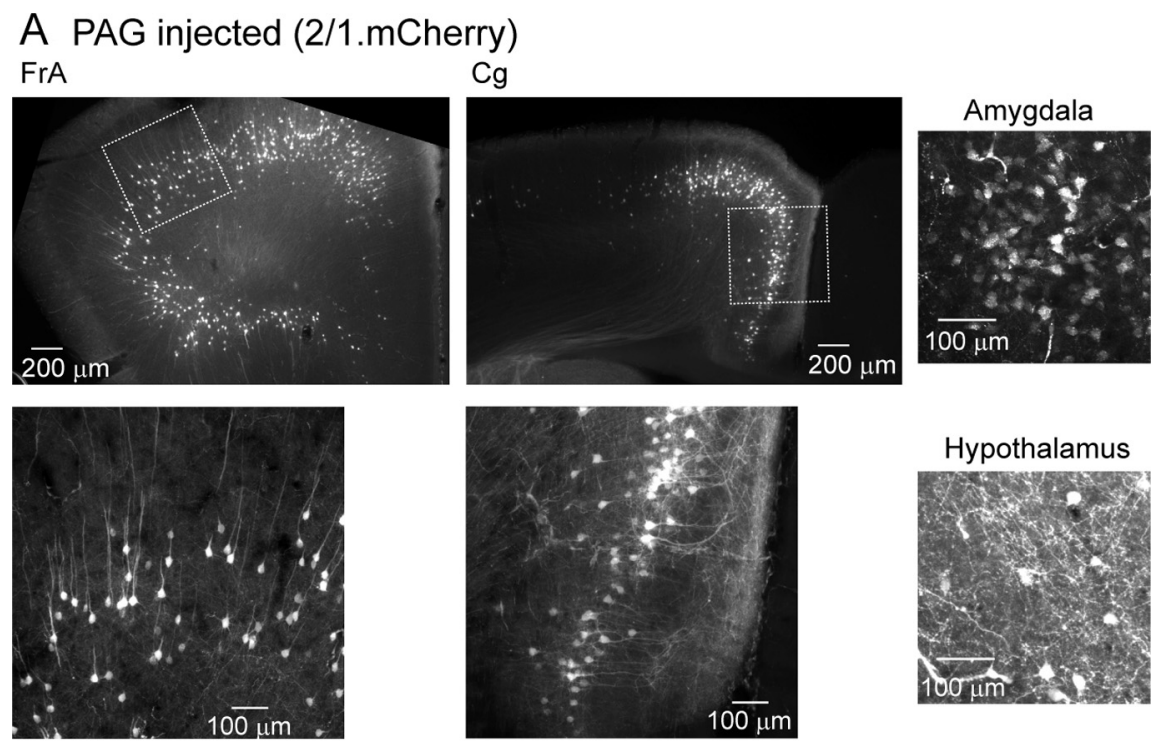

\section{B CPu injected (TH-Cre)}

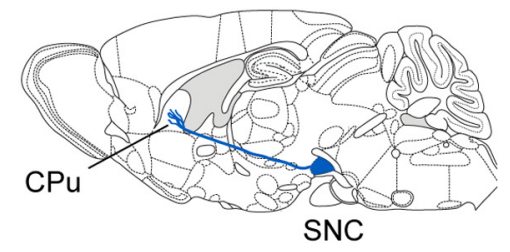

lateral $0.72 \mathrm{~mm}$

\section{PrL/IL and NAc injected (TH-Cre)}

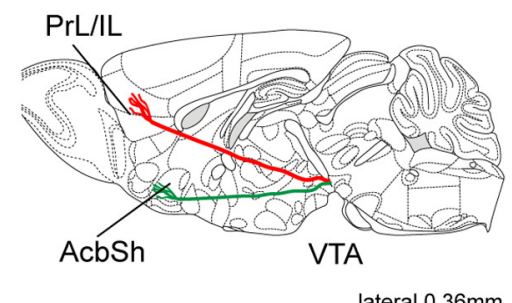

lateral $0.36 \mathrm{~mm}$

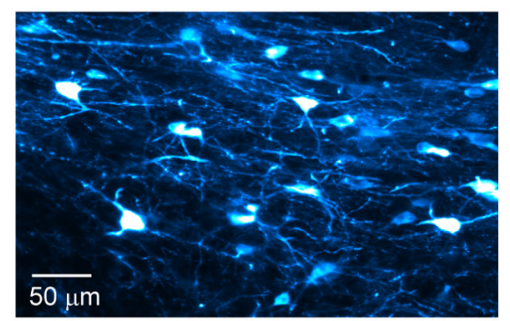

2/1.FLEX.GCaMP3

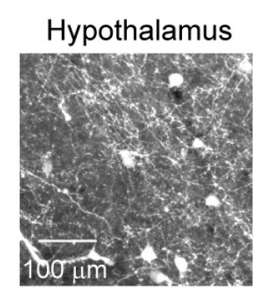

Retrograde expression in target-defined subsets of centrifugal projection neurons

Retrograde viral infection is also useful for isolating subsets of neurons that mediate centrifugal feedback or neuromodulation in a particular brain region. We thus tested the ability of rAAVs to isolate target-defined populations of centrifugal neurons. First we tested two systems that modulate olfactory processing in the OB: descending projections from the anterior olfactory nucleus (AON; Shipley and Adamek, 1984; Markopoulos et al., 2012) and GABAergic projections from the basal forebrain (Ma and Luo, 2012; Zaborszky et al., 2012). A large population of descending $\mathrm{AON}$ projection neurons target the $\mathrm{OB}$, with neurons throughout AON projecting to the ipsilateral and, to a lesser extent, contralateral OB (Shipley and Adamek, 1984). AON projections also target other forebrain areas, such as piriform cortex (Brunjes et al., 2005; Hagiwara et al., 2012). Because of evidence that $\mathrm{AON}$ projection neurons may contain the peptide transmitter cholecystokinin (CCK; Burgunder and Young, 1990; Schiffmann and Vanderhaeghen, 1991), we used CCK-Cre mice to attempt to retrogradely label neurons projecting from $\mathrm{AON}$ to the $\mathrm{OB}$ by injecting Cre-dependent rAAV (2/1.FLEX.GCaMP3) into the $\mathrm{OB}$ on one side (two mice, two injections). In addition to expression in CCKpositive tufted cells of the $\mathrm{OB}$ due to direct infection (Seroogy et al., 1985), virus injection led to strong expression in large numbers of neurons with somata throughout the ipsilateral AON (Fig. 4A), as well as sparser expression in neurons of the contralateral AON (Fig. 4A, inset). Likewise, we isolated GABAergic projections from the horizontal limb of the diagonal band of Broca (HDB), the source of GABAergic basal forebrain projections to the $\mathrm{OB}$ (Shipley and Adamek, 1984; Zaborszky et al., 2012) by injecting 2/1.FLEX.GCaMP3 into the OBs of mice expressing Cre in GAD65-positive neurons (GAD2-Cre mice; three mice, six injections). In addition to the expected expression in GABAergic interneurons of the OB (Wachowiak et al., 2013), GCaMP3 expression also occurred in neurons throughout HDB (Fig. 4B). Retrograde expression was more sparse than was evident after direct virus injection into HDB (Fig. 4B; 32\% of neurons labeled by direct HDB injection;

injected AAV2/1 Cre-dependent vectors into contralateral S1 and superior colliculus in the same mouse $(n=2$ mice). As predicted from the single-injection experiments and from prior retrograde tracing studies (Larsen et al., 2007), these injections resulted in labeling of nonoverlapping populations of pyramidal neurons (Fig. $3 G$ ). mean of 75 vs 235 neurons per counted section; four injections, two mice) consistent with only a subpopulation of these neurons projecting to the $\mathrm{OB}$.

We also tested for retrograde infection of serotonergic projection neurons, which project to multiple targets throughout the brain from the midbrain raphe nuclei. Cre-dependent rAAV 
Table 2. Projection neurons subpopulations showing retrograde transgene expression with rAAV constructs ${ }^{a}$

\begin{tabular}{|c|c|c|c|c|}
\hline Projection target & Source & Distance (mm) & Expression locus (-Cre mouse) & Vector \\
\hline $\mathrm{CPu}$ & SNC & 3.5 & TH & 2/1.FLEX.GCaMP3 \\
\hline AcbSh & VTA & 4.4 & TH & 2/1.FLEX.GCaMP3 \\
\hline $\mathrm{PrL} / \mathrm{IL}$ & VTA & 5.0 & $\mathrm{TH}$ & 2/1.FLEX.GCaMP3; 2/1.FLEX.tdTomato \\
\hline BLA & DR & 5.4 & SERT & 2/9.DI0.hChR2-EYFP \\
\hline $\mathrm{aPC}$ & $O B$ & 2.7 & PCdh21 & See Table 1 \\
\hline $\mathrm{pPC}$ & $O B$ & 5.3 & PCdh21 & See Table 1 \\
\hline $\mathrm{PLC}$ & $\mathrm{OB}$ & 6.8 & $P C d h 21$ & See Table 1 \\
\hline MeA & $A O B$ & 4.6 & $P(d h 21$ & See Table 1 \\
\hline$O B$ & AON & 2.2 & CCK & 2/1.FLEX.GCaMP3 \\
\hline$O B$ & $\mathrm{HDB}$ & 4.3 & GAD65 & 2/1.FLEX.GCaMP5G \\
\hline $\mathrm{OB}$ & $\mathrm{HDB}$ & 4.3 & ChAT & 2/5.DI0.hChR2-EYFP \\
\hline CS1BF (contra) & S1BF & 6.0 (lateral) & WT, Emx1 (cortical pyramidal neurons) & 2/1.FLEX.GCaMP3; 2/1.FLEX.tdTomato; 2/1.mCherry \\
\hline SC & S1BF & 1.9 & WT, Emx1 (cortical pyramidal neurons) & 2/1.FLEX.GCaMP3; 2/1.mCherry \\
\hline Thalamus & S1BF & 2.5 (diagonal) & WT (cortical pyramidal neurons) & 2/1.mCherry \\
\hline
\end{tabular}

${ }^{a}$ Table summarizes virus injection sites and Cre expression loci resulting in retrograde transgene expression after infection by rAAV constructs. Viral constructs were injected into the projection targets of cells located in the source area. Reported distance between the injection site and source area is the straight-line distance in the anterior-posterior direction unless otherwise noted. Expression locus represents mouse line expressing Cre from the designated locus. For WT mice, the targeted neuron types are listed. A0B, Accessory olfactory bulb; BLA, basolateral amygdaloid nucleus, anterior part; (Pu, caudate putamen (striatum), DR, dorsal raphe nucleus; MeA, medial amygdaloid nucleus, anterior part; PLC0, posterolateral cortical amygdaloid nucleus; PPC, posterior piriform cortex; S1BF, primary somatosensory cortex, barrel field; SC, superior colliculus; SNC, substantia nigra, pars compacta.

(2/9.DIO.ChR2-EYFP) was injected into the basolateral amygdala (three mice, six injections) of Slc6a4 (SERT)-Cre mice, which express Cre selectively in serotonergic neurons (Zhuang et al., 2005). Basolateral amygdala receives relatively strong innervation from serotonergic raphe neurons (Vertes, 1991). Consistent with this, virus injection led to ChR2-eYFP expression in substantial numbers of neurons throughout the raphe nuclei ( $n=671$ cells; 17 sections, two mice), with the majority of expressing somata in the dorsal raphe (Fig. 4C). Together these results indicate that retrograde infection using rAAVs can also be used to isolate otherwise indistinguishable subpopulations of centrifugal or neuromodulatory projection neurons based on the target of their axonal projections.

\section{Retrograde transgene expression in neurons projecting to and from midbrain nuclei}

We next targeted projections to and from specific nuclei of the midbrain, a phylogenetically more primitive brain structure that receives input from and sends projections to diverse brain regions. Isolating subsets of midbrain projection neurons based on projection target or source is thus a useful application of retrograde viral tracing. First we used the constitutive AAV 2/1.mCherry to test for retrograde infection of neurons projecting to the periaqueductal gray (PAG). The PAG represents an interface between the forebrain and the lower brainstem and receives input from diverse brain areas (Benarroch, 2012). AAV 2/1.mCherry injection into the PAG resulted in, besides expression in PAG neurons themselves, mCherry expression in substantial numbers of neurons with somata in frontal association cortex, cingulate cortex, hypothalamus, and the amygdala (Fig. 5A). Neurons with somata along the ventricles between the midbrain and frontal cortex showed no infection, indicating specific retrograde tracing and not an unspecific diffusion along the ventricle.

We next tested for retrograde infection of dopaminergic midbrain projection neurons, which originate in several midbrain nuclei and project to multiple forebrain targets. First, injection of 2/1.FLEX.GCaMP3 into the striatum (caudate putamen) of THCre mice (four mice, four injections) labeled neurons in substantia nigra pars compacta (Fig. $5 B$ ) that were pyramidal in shape with rostrocaudally oriented dendrites, matching earlier descriptions of substantia nigra neurons projecting to striatum (Fallon et al., 1978; Faull and Mehler, 1978). Notably, these results differ from recent studies finding that constitutive vectors using the native AAV2 serotype failed to drive retrograde expression in nigrostriatal projection neurons (Ciesielska et al., 2011; Salegio et al., 2013) but appear similar to the levels of retrograde expression mediated by other retrogradely infecting AAV serotypes (Ciesielska et al., 2011; Masamizu et al., 2011; Salegio et al., 2013). Second, we labeled neurons projecting from the ventral tegmental area (VTA) to distinct forebrain targets (Margolis et al., 2006) by injecting 2/1.FLEX.tdTomato or 2/1.FLEX.GCaMP3 into either prelimbic/infralimbic cortex (PrL/IL; three mice, three injections) or nucleus accumbens shell (AcbSh; four mice, four injections) of TH-Cre mice. In each case, injection led to expression in sparsely distributed neurons in VTA. Injection of virus into $\mathrm{PrL} / \mathrm{IL}$ and AcbSh in the same TH-Cre mouse resulted in labeling of distinct (though still sparse) subsets of VTA neurons (Fig. 5C); these results are consistent with previous retrograde labeling studies using histochemical markers (Margolis et al., 2006).

Table 2 summarizes all virus injection sites used to evaluate retrograde infection capabilities of rAAV constructs. Together these results indicate that retrograde infection by a variety of rAAVs can be used to isolate diverse subpopulations of neurons based on the target of their axonal projections.

\section{Optogenetic identification of target-defined projection neurons in vivo using retrograde expression of $\mathrm{ChR} 2$}

We have recently demonstrated that expression of GCaMPs via retrograde infection yields sufficient expression levels to support the selective imaging of spontaneous and odorant-evoked activity from aPC-projecting MTCs in vivo (Wachowiak et al., 2013). Here, we tested whether this approach yields sufficient expression levels to support the identification and physiological characterization of cell types based on projection target. This process is equivalent to the ChR2-assisted circuit mapping approach described recently (Petreanu et al., 2007) but in the retrograde direction. ChR2 (H134R) was expressed in MTCs projecting to aPC via retrograde rAAV infection and "blind" whole-cell or extracellular recordings were obtained from neurons in the OB. For in vivo extracellular or whole-cell recordings, neurons in the dorsal OB were targeted and brief (5-10 ms) light pulses were delivered to the dorsal OB to test for ChR2 expression in the recorded cells. For in vitro whole-cell recordings, mitral cells were visually targeted in $\mathrm{OB}$ slices using differential interference contrast optics and light pulses (3-5 ms) delivered to the entire slice. In all three cases, ChR2-expressing neurons were distinguished by reliable 
(95-100\%) light-evoked spikes (for extracellular recordings) or depolarizing potentials and spike bursts (for whole-cell recordings) occurring with latencies of $<10 \mathrm{~ms}$ and low jitter (SD of spike time, 0.2-1.9 ms; Fig. 6), consistent with other characterizations of responses of ChR2-expressing neurons to light flashes (Arenkiel et al., 2007; Zhang et al., 2013). In the OB slice recordings, five of seven recorded mitral cells (in two mice) showed light-evoked responses meeting these criteria. In the in vivo whole-cell recordings, five of eight cells (in five mice) responded reliably to light stimulation; one of these five was recovered and confirmed to be a mitral cell. Two of the three cells showing no or longer-latency responses to light stimulation were recovered and identified as a superficial tufted cell and a granule cell (data not shown). These results demonstrate that retrograde viral infection with optogenetic transgenes can enable the isolation of genetically specified cell types projecting to specific target locations for in vivo or in vitro analysis.

\section{Discussion}

AAV vectors based on the AAV2 serotype have emerged as a widely used platform for the delivery of transgenes to neurons of the CNS for experimental as well as therapeutic applications $(\mathrm{Wu}$ et al., 2006; Betley and Sternson, 2011; Salegio et al., 2012). Several earlier studies have reported efficient retrograde transduction mediated by other AAV serotypes (for example, AAVs 5, 6, and 9, but ineffective retrograde transduction by AAV2; Paterna et al., 2004; Chen et al., 2013; Salegio et al., 2013). Recombinant, pseudotyped AAVs (rAAVs) engineered to improve transduction efficiency and tissue tropism using capsid genes from other AAV serotypes (Gao et al., 2002; Rabinowitz et al., 2004) have been reported to mediate retrograde transduction in certain projection neuron populations in the rodent and primate CNS (Kaspar et al., 2002; Passini et al., 2005; Taymans et al., 2007; Yasuda et al., 2007; Towne et al., 2009; Masamizu et al., 2011; Zhang et al., 2013). However, other studies have found pseudotyped rAAVs to be poor or ineffective at retrograde transduction (Chamberlin et al., 1998; Burger et al., 2004); indeed, rAAVs based on the AAV2 serotype (e.g., AAV2/1) have been the vector of choice for the large-scale mapping of anterograde axonal projections in the mouse brain (Allen Brain Institute, http://help.brain-map. org/display/mouseconnectivity/Documentation; Harris et al., 2012). Recent iterations of rAAVs feature DNA constructs with optimized promoters, conditional expression switches, and novel fluorophores, as well as optimized methods for purification of high-titer virus (Ayuso et al., 2010; Betley and Sternson, 2011); these vectors have been widely adopted for applications aimed at the functional dissection and manipulation of genetically defined neuronal subpopulations in the intact brain (Luo et al., 2008; Yizhar et al., 2011). Here, we present an extensive study of the retrograde infection abilities of many of the most widely used rAAV vectors for such applications. We tested 13 different rAAVs from two different vector core production facilities (the University of Pennsylvania and the University of North Carolina) and targeted neurons projecting from 14 different brain structures.

We found that many of rAAV vectors - in particular, though not exclusively, those using Cre-dependent expression switchesshow a robust capacity for retrograde infection and subsequent transgene expression in the mouse. The substantial distances between injection site and expressing somata (up to almost $7 \mathrm{~mm}$; Table 2) and the lack of expression in neurons in between these two areas rule out the possibility that these results could be mediated by bulk movement of virus from the injection site. We obtained robust and efficient retrograde expression in Cre-

\section{A}

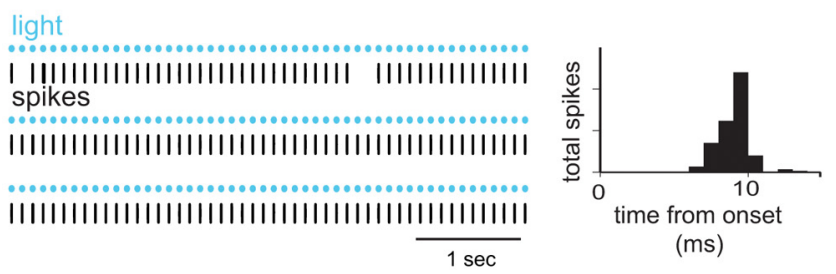

B
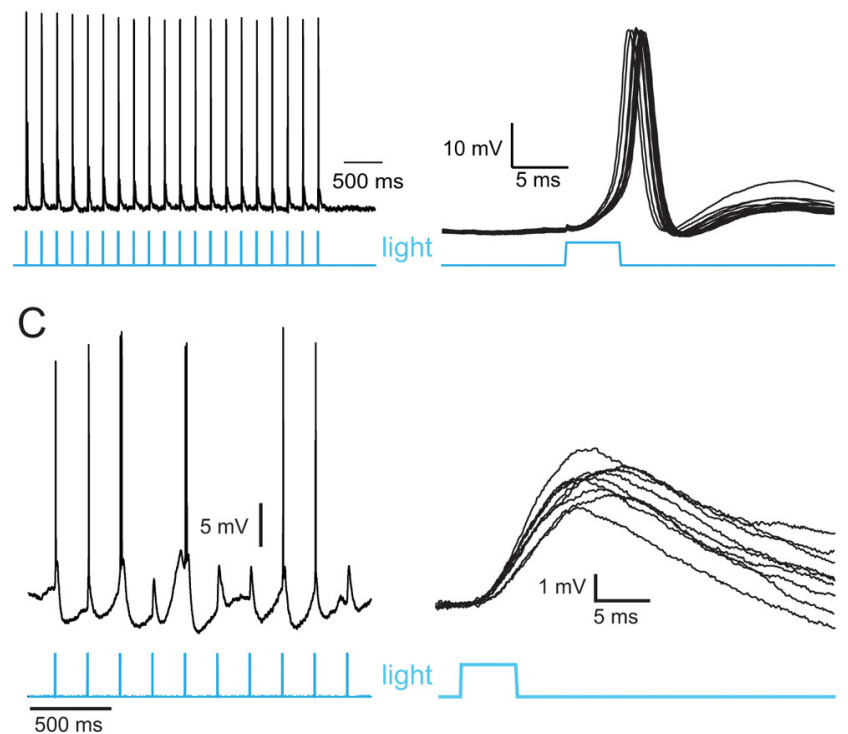

Figure 6. Optogenetic identification of target-defined $O B$ projection neurons after retrograde expression of ChR2. A, In vivo extracellular recording from an MTC in the mouse $\mathrm{OB}$ after injection of 2.1.DI0.hChR2(H134R)-EYFP into aPC of a PCdh21-Cre mouse. Top, Three trials of 50 light pulses (10 ms duration, $10 \mathrm{~Hz}, 200 \mu \mathrm{m}$ optical fiber, $\sim 1 \mathrm{~mW}$ total power at the fiber tip) elicits a single spike following each pulse with near 100\% reliability. Bottom, Pulse-triggered spike histogram showing spike latencies of $8-10 \mathrm{~ms}$ with little jitter. $\boldsymbol{B}$, In vitro whole-cell recording from a mitral cell in an $\mathrm{OB}$ slice after retrograde ChR2 expression in MTCs (PCdh21-Cremouse, as in A). Top trace shows responses to a train of light pulses ( $5 \mathrm{~ms}$ duration, $5 \mathrm{~Hz}, 1 \mathrm{~mm}$ optical fiber, $\sim 24 \mathrm{~mW}$ total power), with each pulse eliciting a spike. Lower trace shows overlay of the response to each pulse in the train, showing short latency to depolarization onset and low jitter in spike time. C, In vivo whole-cell recording from an MTC after retrograde ChR2 expression, as in $\boldsymbol{A}$ and $\boldsymbol{B}$. Left trace shows continuous recording of response to train of 10 pulses (11 $\mathrm{mW}$ total power) delivered as in $\boldsymbol{B}$. In this cell, the light pulse does not always evoke a spike; right traces show overlay of responses to pulses that fail to evoke a spike. Failed responses consist of a depolarization with short latency (2-3 ms) and no detectable jitter in onset time. Higher intensities ( $\leq 25 \mathrm{~mW}$ total power) or longer durations elicited spikes to each pulse (data not shown).

expressing projection neurons using multiple rAAV serotypes and transgenes, multiple Cre mouse lines, and in multiple neuron types including olfactory projection neurons, cortical pyramidal cells, corticofugal projection neurons, and neurons projecting from neuromodulatory centers to different forebrain targets. Retrograde transduction efficiency appeared comparable to or greater than that for the same projection neuron populations targeted in earlier studies using recombinant rabies virus as a "benchmark" retrograde viral tracer (Larsen et al., 2007); likewise we observed retrograde expression patterns in corticothalamic and nigrostriatal projection neurons that appeared qualitatively similar and occurred over a similar or shorter incubation time to those mediated by other native AAV serotypes identified as efficient retrograde transduction vectors (Ciesielska et al., 2011; Masamizu et al., 2011; Salegio et al., 2013). Retrogradely mediated transgene expression levels were strong enough to support optical imaging or 
optogenetic activation of target-defined projection neuron subpopulations in vivo.

Surprisingly, we found dramatic differences in the ability of rAAVs of identical serotype to mediate retrograde transduction depending on the vector construct. For example, 2/1.FLEX. GCaMP5G drove strong retrograde expression in Cre-expressing MTCs of the OB, but the identical construct without the FLEX switch (2/1.GCaMP5G) yielded no retrograde expression in the same mice. Indeed, every Cre-dependent vector tested was capable of driving strong retrograde transgene expression in OB projection neurons and Cre-dependent vectors of the appropriate serotype were effective at driving expression in diverse projection neuron populations. Likewise, one of the three constitutive vectors tested (2/1.mCherry) was highly effective at retrograde infection while others (e.g., 2/1.eGFP) were ineffective. These results speak against the possibility that the presence of Cre aids in axonal transport or genome processing, as some constitutive constructs failed to retrogradely express in Cre-expressing neurons while others (e.g., 2/1.mCherry) led to strong retrograde expression in wild-type mice. Thus, differences in retrograde expression success appear to be determined by the rAAV itself. While viral titer and purification method can affect transduction efficiency (Wu et al., 2006; Towne et al., 2010), reported titers were similar for all constructs tested here and purification method was identical (http://www.med.upenn.edu/gtp/vectorcore/quality_ control.shtml).

The apparent importance of vector DNA composition in the efficiency of retrograde infection by rAAVs is surprising and, to our knowledge, has not been previously reported. Instead, residues in the genome encoding the rAAV capsid are thought to be the chief determinants affecting the neurotropism and intracellular processing of the viral genome and genome unpackaging is thought to occur only after retrograde transport and nuclear entry of the virus particle (Wu et al., 2006; Naumer et al., 2012; Nonnenmacher and Weber, 2012). At present, however, the factors affecting viral transduction efficiency remain unclear and the relationship between vector genome and retrograde transduction requires further exploration (Wu et al., 2006; Naumer et al., 2012; Nonnenmacher and Weber, 2012).

Despite this uncertainty, the robust capacity of the latest generation of rAAVs for retrograde transduction constitutes an important expansion of the toolbox for cell-type-specific isolation and manipulation of neurons in the CNS. For example, Credependent rAAV vectors allow for a combinatorial strategy for defining neuronal populations based on genetic and anatomic criteria and offer advantages over rabies-based and herpes-based vectors in their relative ease of production and handling and their relatively stable, long-term expression of transgenes (Howarth et al., 2010; Betley and Sternson, 2011). The retrograde expression abilities of these vectors also enables the simultaneous expression of different fluorophores, optical reporters, or optogenetic probes in distinct projection streams from the same brain area. Finally, the ability to retrogradely (or directly) drive expression of more than one transgene in the same neuron allows for additional combinatorial possibilities for circuit mapping as well as genetically manipulating neuronal function based on axonal projection patterns. Given the recent surge in efforts to map connectivity and probe circuit function in the intact brain (Luo et al., 2008; Arenkiel and Ehlers, 2009; Yizhar et al., 2011; Alivisatos et al., 2012; Osten and Margrie, 2013), further optimization of retrograde gene transfer using rAAVs is a promising avenue for improved experimental approaches to understanding brain circuits as well as for the continued development of gene therapy applications to treating CNS disorders (Kaspar et al., 2002; Han and Friedman, 2012; Weinberg et al., 2013).

\section{References}

Alivisatos AP, Chun M, Church GM, Greenspan RJ, Roukes ML, Yuste R (2012) The Brain Activity Map Project and the challenge of functional connectomics. Neuron 74:970-974. CrossRef Medline

Arenkiel BR, Ehlers MD (2009) Molecular genetics and imaging technologies for circuit-based neuroanatomy. Nature 461:900-907. CrossRef Medline

Arenkiel BR, Peca J, Davison IG, Feliciano C, Deisseroth K, Augustine GJ, Ehlers MD, Feng G (2007) In vivo light-induced activation of neural circuitry in transgenic mice expressing channelrhodopsin-2. Neuron 54 205-218. CrossRef Medline

Ayuso E, Mingozzi F, Montane J, Leon X, Anguela XM, Haurigot V, Edmonson SA, Africa L, Zhou S, High KA, Bosch F, Wright JF (2010) High AAV vector purity results in serotype- and tissue-independent enhancement of transduction efficiency. Gene Therapy 17:503-510. CrossRef Medline

Benarroch EE (2012) Periaqueductal gray: an interface for behavioral control. Neurology 78:210-217. CrossRef Medline

Betley JN, Sternson SM (2011) Adeno-associated viral vectors for mapping, monitoring, and manipulating neural circuits. Hum Gene Ther 22:669-677. CrossRef Medline

Boyd AM, Sturgill JF, Poo C, Isaacson JS (2012) Cortical feedback control of olfactory bulb circuits. Neuron 76:1161-1174. CrossRef Medline

Brunjes PC, Illig KR, Meyer EA (2005) A field guide to the anterior olfactory nucleus (cortex). Brain Res Brain Res Rev 50:305-335. CrossRef Medline

Burger C, Gorbatyuk OS, Velardo MJ, Peden CS, Williams P, Zolotukhin S, Reier PJ, Mandel RJ, Muzyczka N (2004) Recombinant AAV viral vectors pseudotyped with viral capsids from serotypes 1,2 , and 5 display differential efficiency and cell tropism after delivery to different regions of the central nervous system. Mol Ther 10:302-317. CrossRef Medline

Burgunder JM, Young WS 3rd (1990) Cortical neurons expressing the cholecystokinin gene in the rat: distribution in the adult brain, ontogeny, and some of their projections. J Comp Neurol 300:26-46. CrossRef Medline

Callaway EM (2008) Transneuronal circuit tracing with neurotropic viruses. Curr Opin Neurobiol 18:617-623. CrossRef Medline

Carey RM, Wachowiak M (2011) Effect of sniffing on the temporal structure of mitral/tufted cell output from the olfactory bulb. J Neurosci 31: 10615-10626. CrossRef Medline

Chamberlin NL, Du B, de Lacalle S, Saper CB (1998) Recombinant adenoassociated virus vector: use for transgene expression and anterograde tract tracing in the CNS. Brain Res 793:169-175. CrossRef Medline

Chen JL, Carta S, Soldado-Magraner J, Schneider BL, Helmchen F (2013) Behaviour-dependent recruitment of long-range projection neurons in somatosensory cortex. Nature 499:336-340. CrossRef Medline

Ciesielska A, Mittermeyer G, Hadaczek P, Kells AP, Forsayeth J, Bankiewicz KS (2011) Anterograde axonal transport of AAV2-GDNF in rat basal ganglia. Mol Ther 19:922-927. CrossRef Medline

Fallon JH, Riley JN, Moore RY (1978) Substantia nigra dopamine neurons: separate populations project to neostriatum and allocortex. Neurosci Lett 7:157-162. CrossRef Medline

Faull RL, Mehler WR (1978) The cells of origin of nigrotectal, nigrothalamic and nigrostriatal projections in the rat. Neuroscience 3:989-1002. CrossRef Medline

Gao GP, Alvira MR, Wang L, Calcedo R, Johnston J, Wilson JM (2002) Novel adeno-associated viruses from rhesus monkeys as vectors for human gene therapy. Proc Natl Acad Sci U S A 99:11854-11859. CrossRef Medline

Ghosh S, Larson SD, Hefzi H, Marnoy Z, Cutforth T, Dokka K, Baldwin KK (2011) Sensory maps in the olfactory cortex defined by long-range viral tracing of single neurons. Nature 472:217-220. CrossRef Medline

Gorski JA, Talley T, Qiu M, Puelles L, Rubenstein JL, Jones KR (2002) Cortical excitatory neurons and glia, but not GABAergic neurons, are produced in the Emx1-expressing lineage. J Neurosci 22:6309-6314. Medline

Haberly LB, Price JL (1977) The axonal projection patterns of the mitral and tufted cells of the olfactory bulb in the rat. Brain Res 129:152-157. CrossRef Medline

Haberly LB, Price JL (1978) Association and commissural fiber systems of the olfactory cortex of the rat. J Comp Neurol 178:711-740. CrossRef Medline 
Hagiwara A, Pal SK, Sato TF, Wienisch M, Murthy VN (2012) Optophysiological analysis of associational circuits in the olfactory cortex. Front Neural Circuits 6:18. CrossRef Medline

Han MH, Friedman AK (2012) Virogenetic and optogenetic mechanisms to define potential therapeutic targets in psychiatric disorders. Neuropharmacology 62:89-100. CrossRef Medline

Harris JA, Wook Oh S, Zeng H (2012) Adeno-associated viral vectors for anterograde axonal tracing with fluorescent proteins in nontransgenic and Cre driver mice. In: Current protocols in neuroscience. Malden, MA: Wiley.

Hattox AM, Nelson SB (2007) Layer V neurons in mouse cortex projecting to different targets have distinct physiological properties. J Neurophysiol 98:3330-3340. CrossRef Medline

Heuer GG, Passini MA, Jiang K, Parente MK, Lee VM, Trojanowski JQ, Wolfe $\mathrm{JH}$ (2002) Selective neurodegeneration in murine mucopolysaccharidosis VII is progressive and reversible. Ann Neurol 52:762-770. CrossRef Medline

Howarth JL, Lee YB, Uney JB (2010) Using viral vectors as gene transfer tools (Cell Biology and Toxicology Special Issue: ETCS-UK 1 day meeting on genetic manipulation of cells). Cell Biol Toxicol 26:1-20. CrossRef Medline

Igarashi KM, Ieki N, An M, Yamaguchi Y, Nagayama S, Kobayakawa K, Kobayakawa R, Tanifuji M, Sakano H, Chen WR, Mori K (2012) Parallel mitral and tufted cell pathways route distinct odor information to different targets in the olfactory cortex. J Neurosci 32:7970-7985. CrossRef Medline

Kaspar BK, Erickson D, Schaffer D, Hinh L, Gage FH, Peterson DA (2002) Targeted retrograde gene delivery for neuronal protection. Mol Ther 5:50-56. CrossRef Medline

Kelly RM, Strick PL (2000) Rabies as a transneuronal tracer of circuits in the central nervous system. J Neurosci Methods 103:63-71. CrossRef Medline

Larsen DD, Wickersham IR, Callaway EM (2007) Retrograde tracing with recombinant rabies virus reveals correlations between projection targets and dendritic architecture in layer 5 of mouse barrel cortex. Front Neural Circuits 1:5. Medline

Lo L, Anderson DJ (2011) A Cre-dependent, anterograde transsynaptic viral tracer for mapping output pathways of genetically marked neurons. Neuron 72:938-950. CrossRef Medline

Luo L, Callaway EM, Svoboda K (2008) Genetic dissection of neural circuits. Neuron 57:634-660. CrossRef Medline

Ma M, Luo M (2012) Optogenetic activation of basal forebrain cholinergic neurons modulates neuronal excitability and sensory responses in the main olfactory bulb. J Neurosci 32:10105-10116. CrossRef Medline

Macrides F, Schneider SP (1982) Laminar organization of mitral and tufted cells in the main olfactory bulb of the adult hamster. J Comp Neurol 208:419-430. CrossRef Medline

Madisen L, Zwingman TA, Sunkin SM, Oh SW, Zariwala HA, Gu H, Ng LL, Palmiter RD, Hawrylycz MJ, Jones AR, Lein ES, Zeng H (2010) A robust and high-throughput Cre reporting and characterization system for the whole mouse brain. Nat Neurosci 13:133-140. CrossRef Medline

Madisen L, Mao T, Koch H, Zhuo JM, Berenyi A, Fujisawa S, Hsu YW, Garcia AJ 3rd, Gu X, Zanella S, Kidney J, Gu H, Mao Y, Hooks BM, Boyden ES, Buzsáki G, Ramirez JM, Jones AR, Svoboda K, Han X, et al. (2012) A toolbox of Cre-dependent optogenetic transgenic mice for light-induced activation and silencing. Nat Neurosci 15:793-802. CrossRef Medline

Margolis EB, Lock H, Chefer VI, Shippenberg TS, Hjelmstad GO, Fields HL (2006) Kappa opioids selectively control dopaminergic neurons projecting to the prefrontal cortex. Proc Natl Acad Sci U S A 103:2938-2942. CrossRef Medline

Markopoulos F, Rokni D, Gire DH, Murthy VN (2012) Functional properties of cortical feedback projections to the olfactory bulb. Neuron 76: 1175-1188. CrossRef Medline

Masamizu Y, Okada T, Kawasaki K, Ishibashi H, Yuasa S, Takeda S, Hasegawa I, Nakahara K (2011) Local and retrograde gene transfer into primate neuronal pathways via adeno-associated virus serotype 8 and 9. Neuroscience 193:249-258. CrossRef Medline

McGarry LM, Packer AM, Fino E, Nikolenko V, Sippy T, Yuste R (2010) Quantitative classification of somatostatin-positive neocortical interneurons identifies three interneuron subtypes. Front Neural Circuits 4:12. CrossRef Medline

Mitsui S, Igarashi KM, Mori K, Yoshihara Y (2011) Genetic visualization of the secondary olfactory pathway in Tbx21 transgenic mice. Neural Syst Circuits 1:5. CrossRef Medline

Nagai Y, Sano H, Yokoi M (2005) Transgenic expression of Cre recombinase in mitral/tufted cells of the olfactory bulb. Genesis 43:12-16. CrossRef Medline

Nagayama S, Enerva A, Fletcher ML, Masurkar AV, Igarashi KM, Mori K, Chen WR (2010) Differential axonal projection of mitral and tufted cells in the mouse main olfactory system. Front Neural Circuits 4.pii:120. CrossRef Medline

Nakajima D, Nakayama M, Kikuno R, Hirosawa M, Nagase T, Ohara O (2001) Identification of three novel nonclassical cadherin genes through comprehensive analysis of large cDNAs. Brain Res Mol Brain Res 94:85-95. CrossRef Medline

Naumer M, Popa-Wagner R, Kleinschmidt JA (2012) Impact of capsid modifications by selected peptide ligands on recombinant adenoassociated virus serotype 2-mediated gene transduction. J Gen Virol 93: 2131-2141. CrossRef Medline

Nonnenmacher M, Weber T (2012) Intracellular transport of recombinant adeno-associated virus vectors. Gene Ther 19:649-658. CrossRef Medline

Osakada F, Mori T, Cetin AH, Marshel JH, Virgen B, Callaway EM (2011) New rabies virus variants for monitoring and manipulating activity and gene expression in defined neural circuits. Neuron 71:617-631. CrossRef Medline

Osten P, Margrie TW (2013) Mapping brain circuitry with a light microscope. Nat Methods 10:515-523. CrossRef Medline

Passini MA, Lee EB, Heuer GG, Wolfe JH (2002) Distribution of a lysosomal enzyme in the adult brain by axonal transport and by cells of the rostral migratory stream. J Neurosci 22:6437-6446. Medline

Passini MA, Macauley SL, Huff MR, Taksir TV, Bu J, Wu IH, Piepenhagen PA, Dodge JC, Shihabuddin LS, O'Riordan CR, Schuchman EH, Stewart GR (2005) AAV vector-mediated correction of brain pathology in a mouse model of Niemann-Pick A disease. Mol Ther 11:754-762. CrossRef Medline

Paterna JC, Feldon J, Büeler H (2004) Transduction profiles of recombinant adeno-associated virus vectors derived from serotypes 2 and 5 in the nigrostriatal system of rats. J Virol 78:6808-6817. CrossRef Medline

Paxinos G, Franklin KBJ (2001) The mouse brain in stereotaxic coordinates, second edition. San Diego: Academic.

Petreanu L, Huber D, Sobczyk A, Svoboda K (2007) Channelrhodopsin-2assisted circuit mapping of long-range callosal projections. Nat Neurosci 10:663-668. CrossRef Medline

Rabinowitz JE, Bowles DE, Faust SM, Ledford JG, Cunningham SE, Samulski RJ (2004) Cross-dressing the virion: the transcapsidation of adenoassociated virus serotypes functionally defines subgroups. J Virol 78: 4421-4432. CrossRef Medline

Salegio EA, Samaranch L, Kells AP, Forsayeth J, Bankiewicz K (2012) Guided delivery of adeno-associated viral vectors into the primate brain. Adv Drug Deliv Rev 64:598-604. CrossRef Medline

Salegio EA, Samaranch L, Kells AP, Mittermeyer G, San Sebastian W, Zhou S, Beyer J, Forsayeth J, Bankiewicz KS (2013) Axonal transport of adenoassociated viral vectors is serotype-dependent. Gene Ther 20:348-352. CrossRef Medline

Scalia F, Winans SS (1975) The differential projections of the olfactory bulb and accessory olfactory bulb in mammals. J Comp Neurol 161:31-55. CrossRef Medline

Schiffmann SN, Vanderhaeghen JJ (1991) Distribution of cells containing mRNA encoding cholecystokinin in the rat central nervous system. J Comp Neurol 304:219-233. CrossRef Medline

Schneider SP, Scott JW (1983) Orthodromic response properties of rat olfactory bulb mitral and tufted cells correlate with their projection patterns. J Neurophysiol 50:358-378. Medline

Schoenfeld TA, Marchand JE, Macrides F (1985) Topographic organization of tufted cell axonal projections in the hamster main olfactory bulb: an intrabulbar associational system. J Comp Neurol 235:503-518. CrossRef Medline

Scott JW, McBride RL, Schneider SP (1980) The organization of projections from the olfactory bulb to the piriform cortex and olfactory tubercle in the rat. J Comp Neurol 194:519-534. CrossRef Medline

Seroogy KB, Brecha N, Gall C (1985) Distribution of cholecystokinin-like immunoreactivity in the rat main olfactory bulb. J Comp Neurol 239: 373-383. CrossRef Medline 
Shipley MT, Adamek GD (1984) The connections of the mouse olfactory bulb: a study using orthograde and retrograde transport of wheat germ agglutinin conjugated to horseradish peroxidase. Brain Res Bull 12:669688. CrossRef Medline

Shipley M, Ennis M, Puche A (2004) The olfactory system. In: The rat nervous system, 3rd edition (Paxinos G, ed), pp 922-963. San Diego: Elsevier.

Skorupa AF, Fisher KJ, Wilson JM, Parente MK, Wolfe JH (1999) Sustained production of beta-glucuronidase from localized sites after AAV vector gene transfer results in widespread distribution of enzyme and reversal of lysosomal storage lesions in a large volume of brain in mucopolysaccharidosis VII mice. Exp Neurol 160:17-27. CrossRef Medline

Taniguchi H, He M, Wu P, Kim S, Paik R, Sugino K, Kvitsiani D, Kvitsani D, Fu Y, Lu J, Lin Y, Miyoshi G, Shima Y, Fishell G, Nelson SB, Huang ZJ (2011) A resource of Cre driver lines for genetic targeting of GABAergic neurons in cerebral cortex. Neuron 71:995-1013. CrossRef Medline

Taymans JM, Vandenberghe LH, Haute CV, Thiry I, Deroose CM, Mortelmans L, Wilson JM, Debyser Z, Baekelandt V (2007) Comparative analysis of adeno-associated viral vector serotypes $1,2,5,7$, and 8 in mouse brain. Hum Gene Ther 18:195-206. CrossRef Medline

Towne C, Pertin M, Beggah AT, Aebischer P, Decosterd I (2009) Recombinant adeno-associated virus serotype 6 (rAAV2/6)-mediated gene transfer to nociceptive neurons through different routes of delivery. Mol Pain 5:52. CrossRef Medline

Towne C, Schneider BL, Kieran D, Redmond DE Jr, Aebischer P (2010) Efficient transduction of non-human primate motor neurons after intramuscular delivery of recombinant AAV serotype 6. Gene Ther 17:141-146. CrossRef Medline

Vertes RP (1991) A PHA-L analysis of ascending projections of the dorsal raphe nucleus in the rat. J Comp Neurol 313:643-668. CrossRef Medline

Wachowiak M, Economo MN, Díaz-Quesada M, Brunert D, Wesson DW, White JA, Rothermel M (2013) Optical dissection of odor information processing in vivo using GCaMPs expressed in specified cell types of the olfactory bulb. J Neurosci 33:5285-5300. CrossRef Medline
Wall NR, Wickersham IR, Cetin A, De La Parra M, Callaway EM (2010) Monosynaptic circuit tracing in vivo through Cre-dependent targeting and complementation of modified rabies virus. Proc Natl Acad Sci U S A 107:21848-21853. CrossRef Medline

Weinberg MS, Samulski RJ, McCown TJ (2013) Adeno-associated virus (AAV) gene therapy for neurological disease. Neuropharmacology 69:82-88. CrossRef Medline

Wickersham IR, Finke S, Conzelmann KK, Callaway EM (2007) Retrograde neuronal tracing with a deletion-mutant rabies virus. Nat Methods 4:4749. CrossRef Medline

Wu Z, Asokan A, Samulski RJ (2006) Adeno-associated virus serotypes: vector toolkit for human gene therapy. Mol Ther 14:316-327. CrossRef Medline

Yasuda T, Miyachi S, Kitagawa R, Wada K, Nihira T, Ren YR, Hirai Y, Ageyama N, Terao K, Shimada T, Takada M, Mizuno Y, Mochizuki H (2007) Neuronal specificity of alpha-synuclein toxicity and effect of Parkin co-expression in primates. Neuroscience 144:743-753. CrossRef Medline

Yizhar O, Fenno LE, Davidson TJ, Mogri M, Deisseroth K (2011) Optogenetics in neural systems. Neuron 71:9-34. CrossRef Medline

Zaborszky L, Van den Pol AN, Gyengesi E (2012) The basal forebrain cholinergic projection system in mice. In: The mouse nervous system (Watson C, Paxinos G, Puelles L, eds), pp 684-718. Amsterdam: Elsevier.

Zhang SJ, Ye J, Miao C, Tsao A, Cerniauskas I, Ledergerber D, Moser MB, Moser EI (2013) Optogenetic dissection of entorhinal-hippocampal functional connectivity. Science 340:1232627. CrossRef Medline

Zhao S, Ting JT, Atallah HE, Qiu L, Tan J, Gloss B, Augustine GJ, Deisseroth K, Luo M, Graybiel AM, Feng G (2011) Cell type-specific channelrhodopsin-2 transgenic mice for optogenetic dissection of neural circuitry function. Nat Methods 8:745-752. CrossRef Medline

Zhuang X, Masson J, Gingrich JA, Rayport S, Hen R (2005) Targeted gene expression in dopamine and serotonin neurons of the mouse brain. J Neurosci Methods 143:27-32. CrossRef Medline 